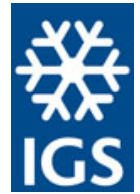

\section{Paper}

Cite this article: Ojala AEK, Peterson G, Mäkinen J, Johnson MD, Kajuutti K, Palmu J-P, Ahokangas E, Öhrling C (2019). Ice-sheet scale distribution and morphometry of triangularshaped hummocks (murtoos): a subglacial landform produced during rapid retreat of the Scandinavian Ice Sheet. Annals of Glaciology 60(80), 115-126. https://doi.org/10.1017/ aog.2019.34

Received: 14 May 2019

Revised: 4 October 2019

Accepted: 4 October 2019

First published online: 28 October 2019

Key words:

Geomorphology; glacial geology; glacier

hydrology; landform; murtoo

Author for correspondence:

Antti E. K. Ojala, E-mail: antti.ojala@gtk.fi

\title{
Ice-sheet scale distribution and morphometry of triangular-shaped hummocks (murtoos): a subglacial landform produced during rapid retreat of the Scandinavian Ice Sheet
}

\section{Antti E. K. Ojala ${ }^{1}$, Gustaf Peterson ${ }^{2,3}$, Joni Mäkinen4, Mark D. Johnson³, Kari Kajuutti ${ }^{4}$, Jukka-Pekka Palmu ${ }^{1}$, Elina Ahokangas ${ }^{4}$ and Christian Öhrling ${ }^{2}$}

${ }^{1}$ Geological Survey of Finland, P.O. Box 96, FI-02151 Espoo, Finland; ${ }^{2}$ Geological Survey of Sweden, P.O. Box 670, SE-75128, Uppsala, Sweden; ${ }^{3}$ Department of Earth Sciences, University of Gothenburg, P.O. Box 460, SE-40530, Gothenburg, Sweden and ${ }^{4}$ Department of Geography and Geology, University of Turku, FI-20014 Turku, Finland

\section{Abstract}

High-resolution digital elevation models of Finland and Sweden based on LiDAR (Light Detection and Ranging) reveal subglacial landforms in great detail. We describe the ice-sheet scale distribution and morphometric characteristics of a glacial landform that is distinctive in morphology and occurs commonly in the central parts of the former Scandinavian Ice Sheet, especially up-ice of the Younger Dryas end moraine zone. We refer to these triangular or $\mathrm{V}$-shaped landforms as murtoos (singular, 'murtoo'). Murtoos are typically $30-200 \mathrm{~m}$ in length and 30-200 $\mathrm{m}$ in width with a relief of commonly $<5 \mathrm{~m}$. Murtoos have straight and steep edges, a triangular tip oriented parallel to ice-flow direction, and an asymmetric longitudinal profile with a shorter, but steeper down-ice slope. The spatial distribution of murtoos and their geomorphic relation to other landforms indicate that they formed subglacially during times of climate warming and rapid retreat of the Scandinavian Ice Sheet when large amounts of meltwater were delivered to the bed. Murtoos are formed under warm-based ice and may be associated with a non-channelized subglacial hydraulic system that evacuated large discharges of subglacial water.

\section{Introduction}

The increased resolution provided by digital elevation models (DEM) based on LiDAR (Light Detection and Ranging) reveals not only well-known glacial landforms in greater detail but landforms new to science. Recent studies describe a distinct triangular or V-shaped glacial landform in the Fennoscandian Shield area (Seppälä, 2016; Mäkinen and others, 2017; Peterson and others, 2017) (Fig. 1). Here we call these landforms 'murtoos' (singular 'murtoo'). Examples of this landform were found near the village of Murtoo, Finland, and the word 'murtoo' in Finnish refers to fragmentary topography. Previously, these triangularshaped landforms have been undetected in Sweden and Finland or have been included in 'hummocky moraine' or 'dead-ice moraine' on many geological survey maps.

Here, we present detailed morphometry of murtoos in Finland and Sweden and discuss their geomorphic relationship to other glacial bedforms. We also present a map of their icesheet scale distribution and show that it is related to major deglacial climatic events including the Bølling-Allerød warm period, Greenland Stadial 1 (when the prominent Younger Dryas end moraines were formed) and postglacial Holocene warming.

Murtoo excavations are being conducted and murtoo sedimentology is described in detail in papers under preparation. The preliminary sedimentological descriptions show, however, that murtoos are composed primarily of loose diamicton with some sorted beds, and are often characterized with numerous surface boulders (Johnson and others, 2018; Kajuutti and others, 2018; Mäkinen and others, 2018; Peterson and others, 2018). These studies particularly indicate that diamicton in murtoos lacks the more compact and homogeneous character of subglacial traction till found in nearby drumlins and till plains, and that in places the interbedded sandy lenses and sandier zones include sedimentary structures that can be slightly to strongly deformed.

Based on the conjugate angles of murtoo sides, Seppälä (2016) suggested that murtoos were formed by subglacial tectonics in which their shape is achieved by fracturing of the subglacial material. A similar genesis was suggested by Frödin (1954) for a V-shaped landform he mapped in Jämtland, Sweden, which represents the only observation of a murtoo-like landform prior to the availability of LiDAR. Based on morphology and some small exposures, Mäkinen and others (2017) interpreted murtoos to be bodies of subglacial till that moved by creep but also were eroded and shaped by subglacial meltwater.

The genesis of murtoos is not clearly understood. An understanding of murtoo genesis will be aided by their morphometric analysis and an ice-sheet scale mapping of their distribution. Thereby, the aims of the present study are to (i) show the morphometric characteristics of murtoos, (ii) demonstrate that murtoos are unique in their morphology compared to other 


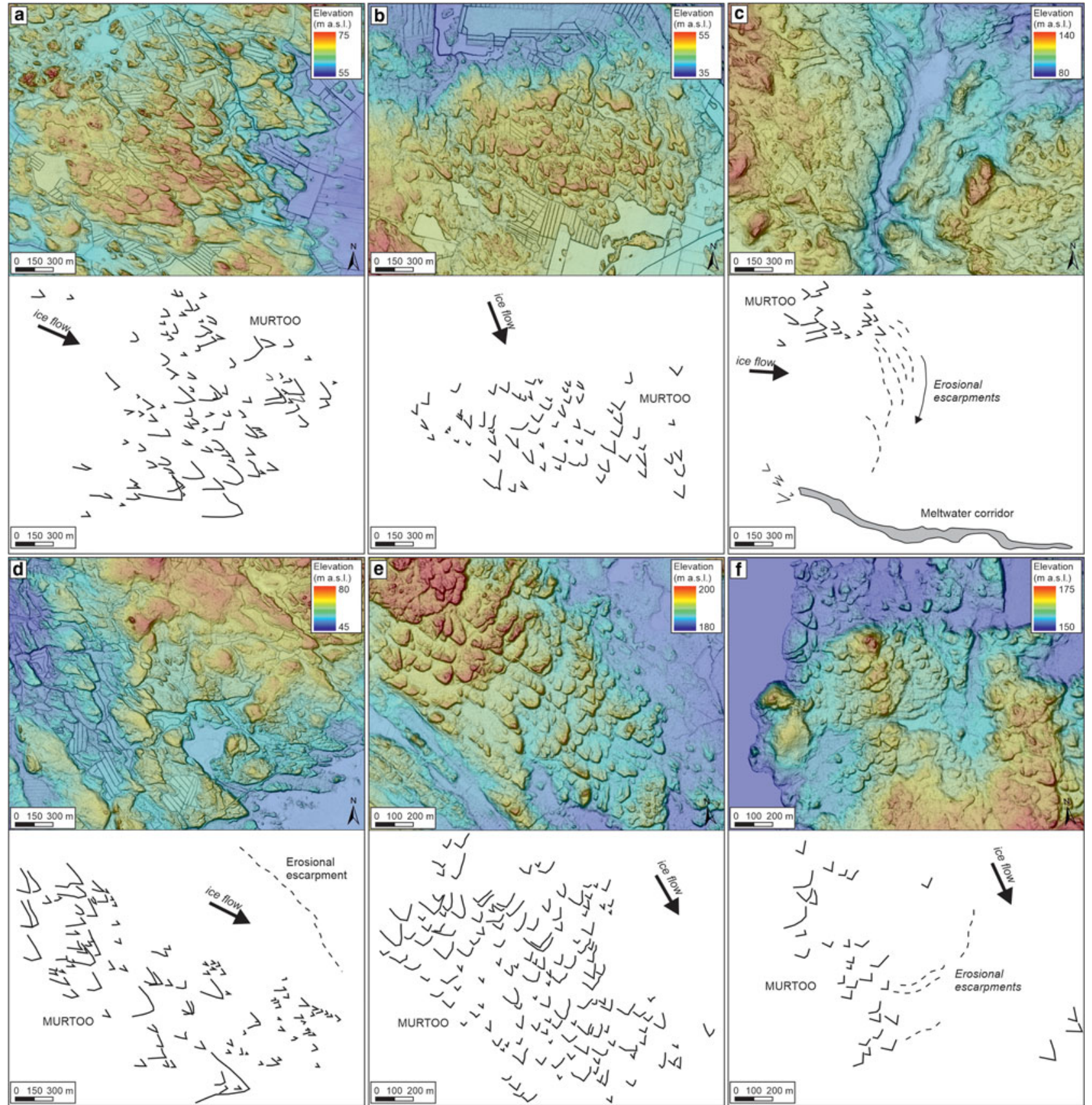

Fig. 1. Typical examples of murtoo fields from Finland and Sweden presented with hillshaded LiDAR $D E M s(A=K y n a ̈ s j a ̈ r v i, ~ B=J o k i s a l o, C=M u r t o o, D=S a ̈ a ̈ k s j a ̈ r v i$, $\mathrm{E}=$ Gullaskruv, $\mathrm{F}=$ Rottnen). Murtoos are easily recognized as the triangular-shaped landforms (brinkline mapped) as indicated in panels below LiDAR DEM images. Black thick arrows indicate the last ice-flow direction and thin arrows meltwater flow during deglaciation. Locations of these examples are given in Figure 10.

glacial landforms, and (iii) discuss their spatial distribution and origin in relation to deglaciation of the Scandinavian Ice Sheet (SIS) and ice-sheet dynamics.

\section{Study area}

The study area is located on the Fennoscandian Shield, which consists predominantly of crystalline bedrock (Koistinen and others, 2001). The study area was completely covered by the SIS during the last glaciation and glacial deposits are predominantly thin (commonly $<10 \mathrm{~m}$ ) over bedrock. Deposits pre-dating the Late Weichselian are rare, most commonly in the far north where cold-bed conditions prevailed during glaciation and preserved them from erosion (Lagerbäck, 1988; Johansson and others, 2011). The southern margin of SIS extended into northern continental Europe and its maximum position was reached first in
Denmark, but progressively later to the east so that the age of this border ranges from 23 to $19 \mathrm{ka}$ BP (Hughes and others, 2015; Stroeven and others, 2016) (Fig. 2). Several prominent endmoraine belts in Germany, Poland and the Baltic States north of the Last Glacial Maximum (LGM) position indicate stillstands or readvances of the ice margin during early deglaciation (Lundqvist and Saarnisto, 1995; Boulton and others, 2001; Stroeven and others, 2016). Continued ice-margin retreat in Finland and Sweden was steady, and except for some prominent moraines along the Swedish southwest coast (Lundqvist and Wohlfarth, 2001), few clear ice-margin positions exist south of the prominent end moraines formed during the Younger Dryas cold event, including the Middle Swedish end-moraine zone and the Salpausselkä moraines in Finland (Fig. 2). The deglaciation north of the Younger Dryas moraines was fast and continuous, involving multiple ice streams in Finland (Kleman and 


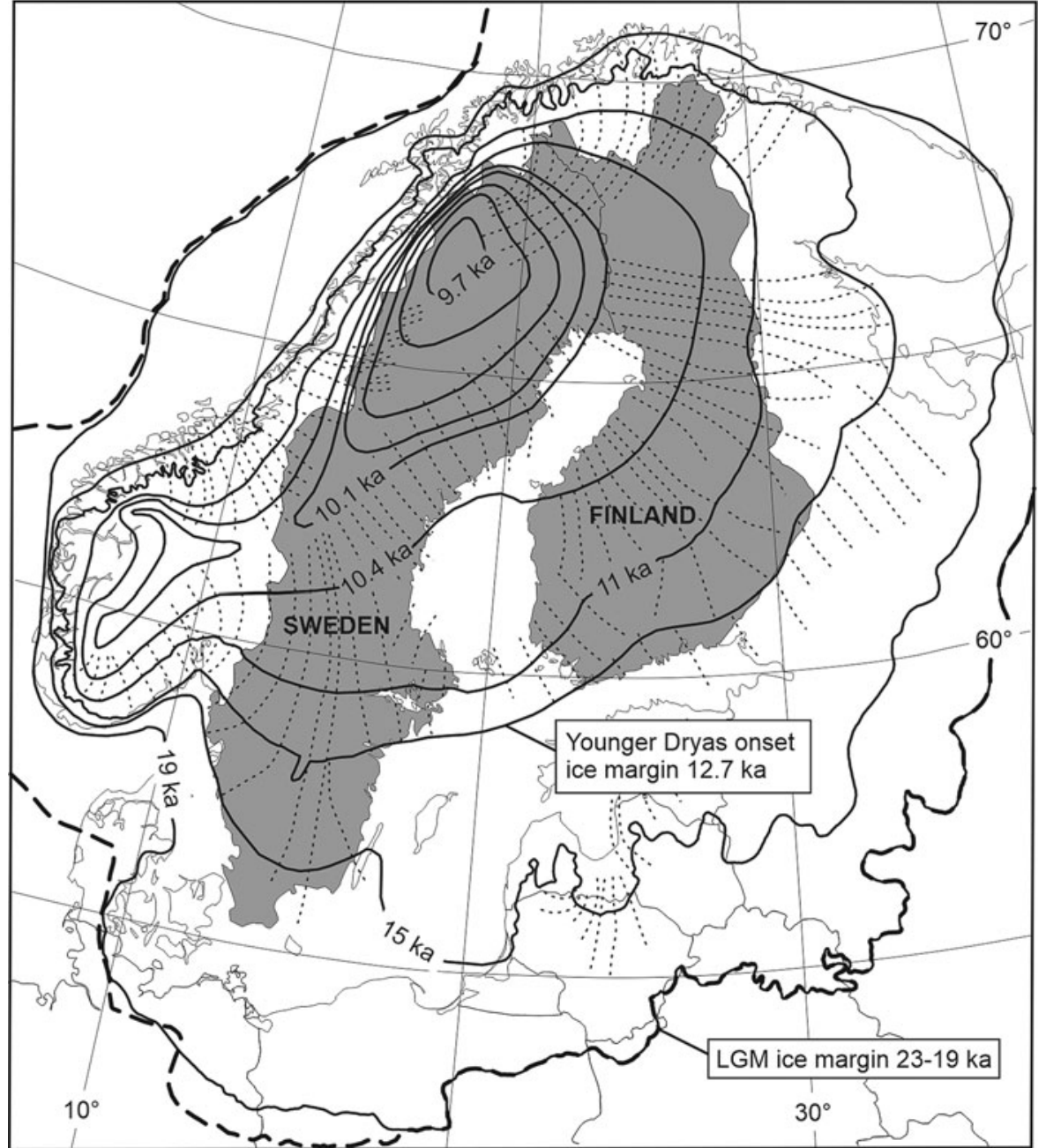

Fig. 2. Selected retreat isochrones of the Scandinavian Ice Sheet (SIS) (modified after Hughes and others, 2015; Stroeven and others, 2016) shown in calibrated kilo years (ka) before present. Flow lines (thin dotted lines) indicate the main deglacial fans based on Kleman and others (1997) and dotted thick line is the maximum SIS extend during the Last Glacial Maximum (LGM).

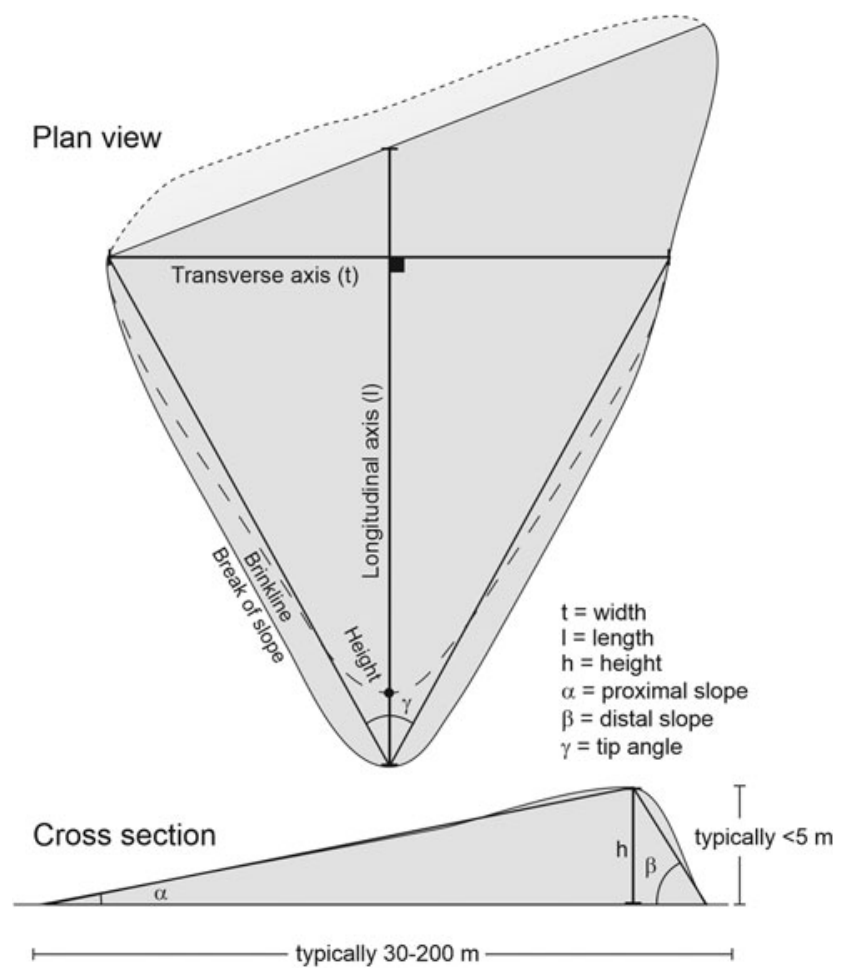

Fig. 3. Measured features and calculated values on a murtoo. On each murtoo $(n=680)$ the 'proximal' break of slope, longitudinal and transversal axis, and height at brinkline was mapped. others, 1997). The final deglaciation progressed rapidly, and the SIS was gone by 9-10 ka BP (Hughes and others, 2015; Stroeven and others, 2016; Regnell and others, 2019) (Fig. 2).

\section{Methods}

\section{Mapping}

In the present study, we screened Sweden and Finland for the spatial distribution of murtoos from LiDAR-based DEM at a scale of 1: 16000 and 1: 20000 . We used two main visualization derivatives that were processed from the LiDAR DEMs: (i) multiple illumination angle rasters $\left(315^{\circ}, 45^{\circ}, 90^{\circ}, 0^{\circ}\right)$ or a multidirectional oblique-weighted hillshade (primary illumination from $325^{\circ}$, vertical exaggeration of 3-5) (Jenness, 2013), and (ii) a slope raster.

\section{Morphometry}

As input for statistical analysis, 56 murtoo fields were randomly selected from the 564 murtoo fields that were found during screening. These selected fields were randomly distributed among four groups of the authors for morphometric analyses, which were done in the ArcMap environment.

The perimeter of each murtoo field was mapped as a polygon feature. The local ice-flow direction was determined using glacial lineations (drumlins, striations) in the vicinity of each murtoo field. Individual murtoos were measured within each field. To accurately describe the morphology of the individual murtoos, the following parameters were measured (Fig. 3). (1) The break of slope (the base of the steep, distal edge) was mapped to outline 

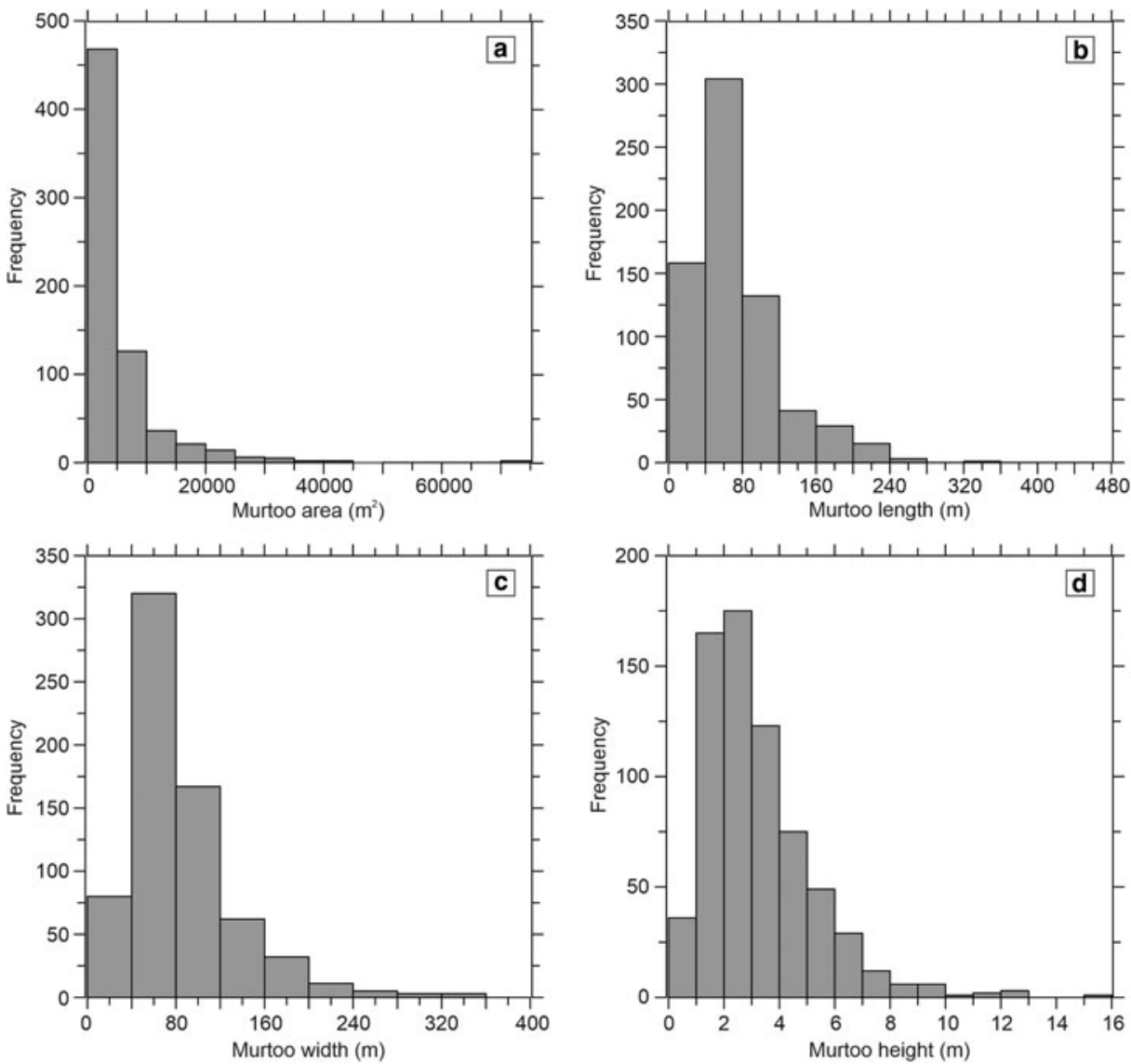

. Murtoo dimension (a-d), horizontal tip angle (e) and proximal and distal slope angles (f) (linear correlation $r^{2}=0.21$ ) measured at the randomly selected murtoo fields $(n=680)$.
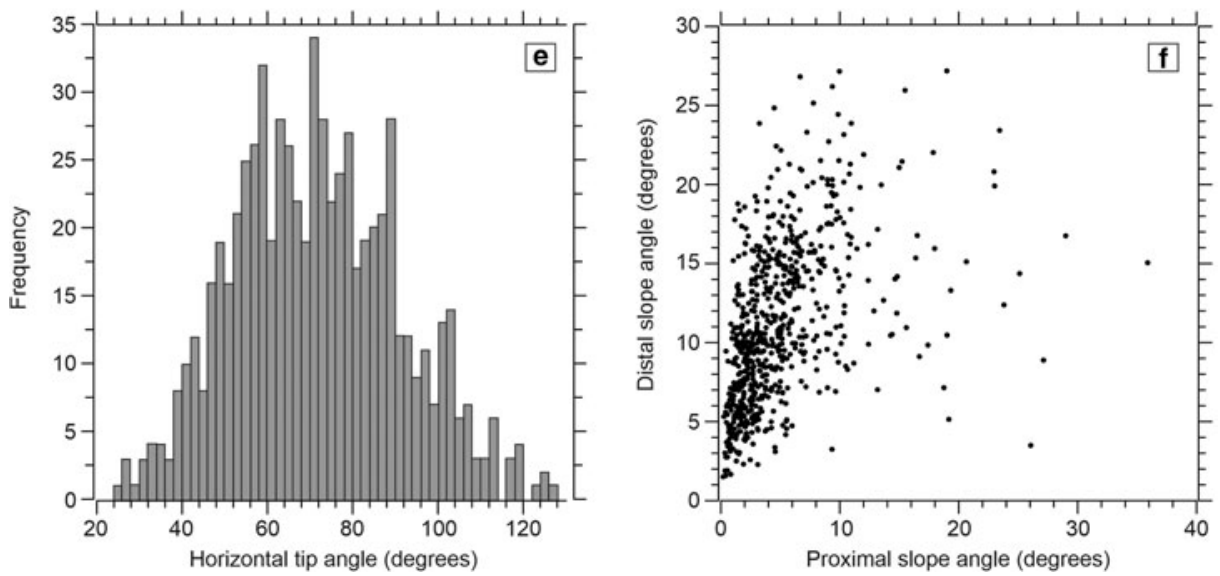

the ' $V$ ' of the landform. (2) The angle defining the tip of the murtoo was visually bisected and measured to represent the murtoo's longitudinal axis. (3) A transverse axis was drawn from side to side of the break of slope, perpendicular to the longitudinal axis extending from the end of the shorter side of the murtoo edge. (4) The highest point along the longitudinal axis where it meets the brinkline was marked.

The collected data were processed using ArcPy (10.5.1) and Python (3.6.6). Standard morphometric attributes such as area, length, width and height were retrieved. The 'tip angle' was calculated using trigonometric functions. The direction of the longitudinal axis and the direction of the local ice flow in the vicinity of the murtoo field were recorded. Additionally, by assigning elevation values from the LiDAR-based DEM, the distal and proximal slopes were calculated.

For each murtoo field, four attributes were retrieved: area of the field, slope along the major axis of the field, number of mapped murtoos per field and the 'geomorphon' in which the murtoo field is situated. A 'geomorphon' (Jasiewicz and
Stepinski, 2013) is a ternary pattern that can describe a terrain morphology and is calculated using the GRASS GIS (7.4.0) on a $30 \mathrm{~m}$ resolution version of the LiDAR-derived DEM (parameters used: search $=1500$, skip $=0$, flat $=1$, dist $=0$ ). The geomorphon method divides the landscape into ten different forms (flat, peak, ridge, shoulder, spur, slope, pit, valley, footslope and hollow) and each field was assigned the value that was most common.

\section{Results}

\section{Description of murtoos}

A total of 56 murtoo fields and 680 individual murtoos were measured in the present study. They show variations in area and slopes as well as width, length, height and horizontal tip angle of murtoos, but the morphological characteristics of murtoos within and between each murtoo field are distinctly similar (Figs 4 and 5). 

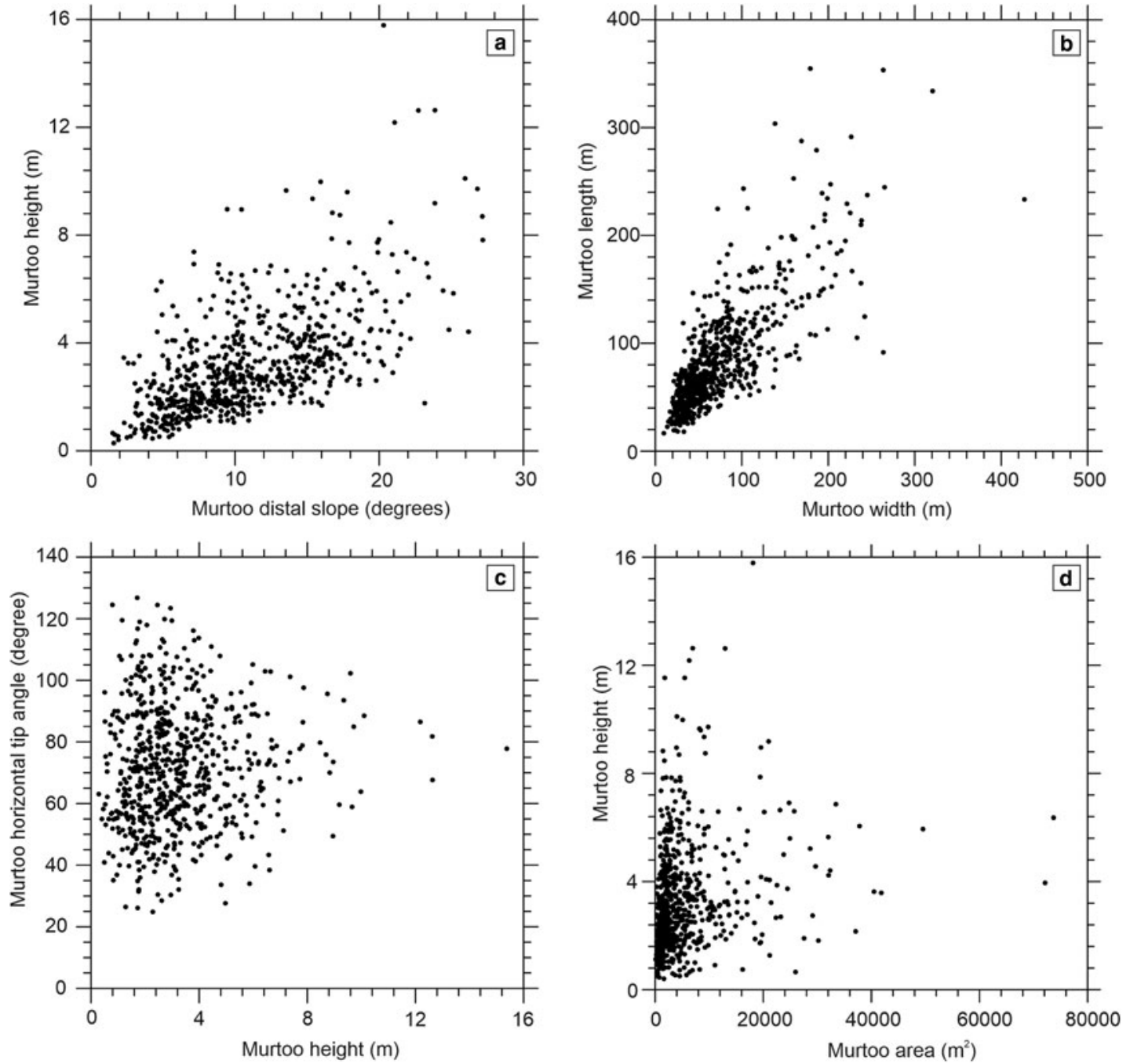

Fig. 5. The relationships for murtoo morphometrics indicate that the height is associated with distal slope (a) (linear correlation $\left.r^{2}=0.37\right)$ and width with length (b) (linear correlation $r^{2}=0.61$ ), but the tip angle vs height (c) is less predictable (linear correlation $r^{2}=0.01$ ), especially for murtoos that are $<4 \mathrm{~m}$ in relief. Murtoo height is independent of murtoo area (d) (linear correlation $r^{2}=0.06$ ).

Table 1. Statistics for selected murtoos $(n=680)$

\begin{tabular}{|c|c|c|c|c|c|c|}
\hline Murtoos & Minimum & $\begin{array}{c}1 \text { st } \\
\text { quartile }\end{array}$ & Median & Mean & $\begin{array}{c}\text { 3rd } \\
\text { quartile }\end{array}$ & Maximum \\
\hline Area $\left(\mathrm{m}^{2}\right)$ & 89.97 & 1420.98 & 2802.47 & 5458.34 & 6149.49 & 73699.99 \\
\hline Length (m) & 9.84 & 41.46 & 59.21 & 74.70 & 91.92 & 426.71 \\
\hline Width (m) & 16.56 & 52.12 & 71.46 & 85.19 & 105.69 & 354.70 \\
\hline Height (m) & 0.29 & 1.87 & 2.78 & 3.24 & 4.09 & 15.78 \\
\hline $\begin{array}{l}\text { Horizontal tip } \\
\text { angle (degrees) }\end{array}$ & 24.83 & 56.94 & 70.83 & 71.56 & 85.40 & 126.78 \\
\hline $\begin{array}{l}\text { Proximal slope } \\
\text { (degrees) }\end{array}$ & 0.19 & 2.08 & 3.70 & 4.92 & 6.16 & 35.88 \\
\hline $\begin{array}{l}\text { Distal slope } \\
\text { (degrees) }\end{array}$ & 1.51 & 7.03 & 10.28 & 11.01 & 14.60 & 27.18 \\
\hline
\end{tabular}

More than $90 \%$ of the measured murtoos are $<10000 \mathrm{~m}^{2}$ (hectare) in area (Fig. 4a), and their area mostly varies between 2000 and $5000 \mathrm{~m}^{2}$ (Table 1 ). Murtoos are typically $30-200 \mathrm{~m}$ long and $30-200 \mathrm{~m}$ wide with a median of 59 and $79 \mathrm{~m}$, respectively (Figs $4 \mathrm{~b}$ and $\mathrm{c}$ ). The relief of murtoos is commonly $<5 \mathrm{~m}$, but in cases up to $10-15 \mathrm{~m}$ (Fig. $4 \mathrm{~d}$ ) with a mean of $\sim 3 \mathrm{~m}$ (Table 1). The values of the murtoo tip angle are normally distributed and generally between $50^{\circ}$ and $90^{\circ}$ (Fig. 4e). The longitudinal profile of murtoos is asymmetric; in most cases the distal slope is steeper than the proximal slope, and can be up to $25-30^{\circ}$ with a median of $10^{\circ}$ (Fig. 4f, Table 1). A linear relationship exists between the distal and proximal slopes, which is particularly well pronounced with less steep $\left(<7^{\circ}\right)$ proximal slopes. Murtoos also exhibit a shingled, fish-scale like appearance where the tips of up-ice murtoos appear to overlap down-ice murtoos (Fig. 1).

When comparing murtoo morphometric variables with each other, it is clear that prominent statistical relationship exists between murtoo dimensions and slopes (Fig. 5). For example, larger murtoos with higher relief are associated with steeper distal slopes. There is also a strong relationship between murtoo length and width (Figs $5 \mathrm{a}$ and $\mathrm{b}$ ). An interesting observation is that for murtoos that are $<5 \mathrm{~m}$ in relief, the horizontal tip angle varies between $20^{\circ}$ and $120^{\circ}$, but for higher relief murtoos $(>5 \mathrm{~m})$, the range of tip angle is narrower and approaches $80^{\circ}$ (Fig. $5 \mathrm{c}$ ). The area of individual murtoos, on the other hand, does not correlate with the steepness of distal or proximal slopes or the height of a murtoo (Fig. 5d), indicating that the relief of a murtoo is independent of its width and length dimensions.

Fields of murtoos are commonly $0.5-4 \mathrm{~km}$ wide and long with a typical area of $<12 \mathrm{~km}^{2}$ (Fig. 6, Table 2). The fields contain from a few to a few tens of murtoos, typically between ten and 50 murtoos with a median of 25 at the presently investigated sites. It is typical that more distinct murtoos appear in the middle of the fields, whereas their striking pattern with sharp edges and clear triangular shape fades towards the fringes of the fields. Murtoos 

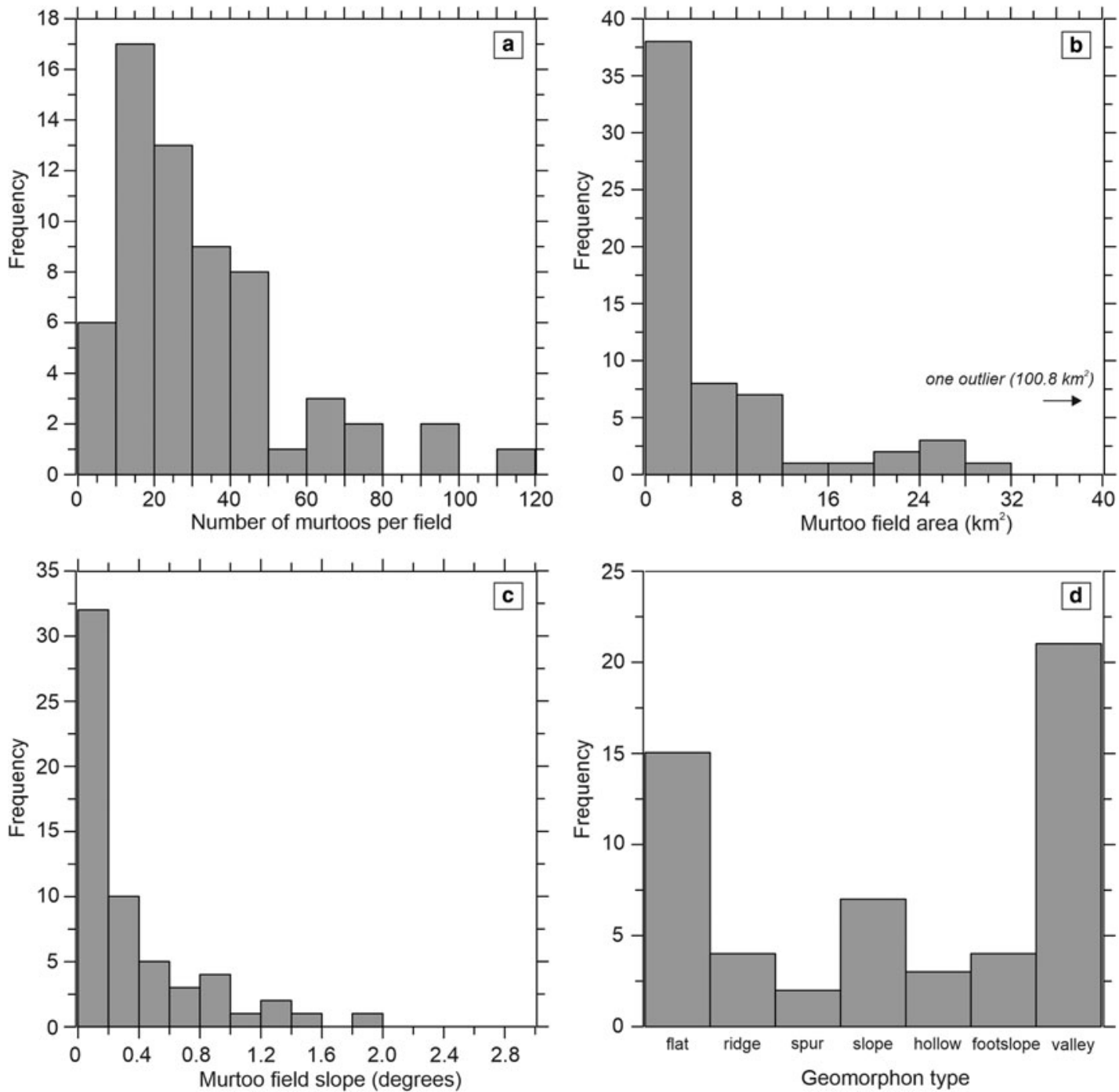

Fig. 6. Number of murtoos in each field (a), murtoo field area (b) and slope (c), and geomorphon type (d) (see Jasiewicz and Stepinski (2013) for geomorphon types) of randomly selected murtoo fields $(n=56)$ investigated in the present study.

Table 2. Statistics for randomly selected murtoo fields $(n=56)$

\begin{tabular}{|c|c|c|c|c|c|c|}
\hline Murtoo fields & Minimum & $\begin{array}{c}\text { 1st } \\
\text { quartile }\end{array}$ & Median & Mean & $\begin{array}{c}\text { 3rd } \\
\text { quartile }\end{array}$ & Maximum \\
\hline $\begin{array}{l}\text { Number of } \\
\text { murtoos }\end{array}$ & 6 & 15.75 & 25 & 33.49 & 44.25 & 119 \\
\hline Area $\left(\mathrm{km}^{2}\right)$ & 0.125 & 1.189 & 3.047 & 8.151 & 9.477 & 100.793 \\
\hline $\begin{array}{l}\text { Slope } \\
\text { (degrees) }\end{array}$ & 0.004 & 0.088 & 0.205 & 0.502 & 0.684 & 3.791 \\
\hline
\end{tabular}

appear in different types of topographic positions (geomorphons), but most commonly in valleys and flat areas (slope $<2^{\circ}$ ) (Fig. 6d).

The orientation of the longitudinal axis of individual murtoos agrees strongly with the mean direction of local ice flow provided by striations and linear landforms (Fig. 7). This shows that the $\mathrm{V}$-shaped form is clearly related to the ice-flow direction.

\section{Murtoos in relation to other glacial landforms}

In a few locations, murtoos are crossed by eskers indicating that they were shaped prior to esker formation. Murtoos are also often associated with eskers longitudinally with murtoos

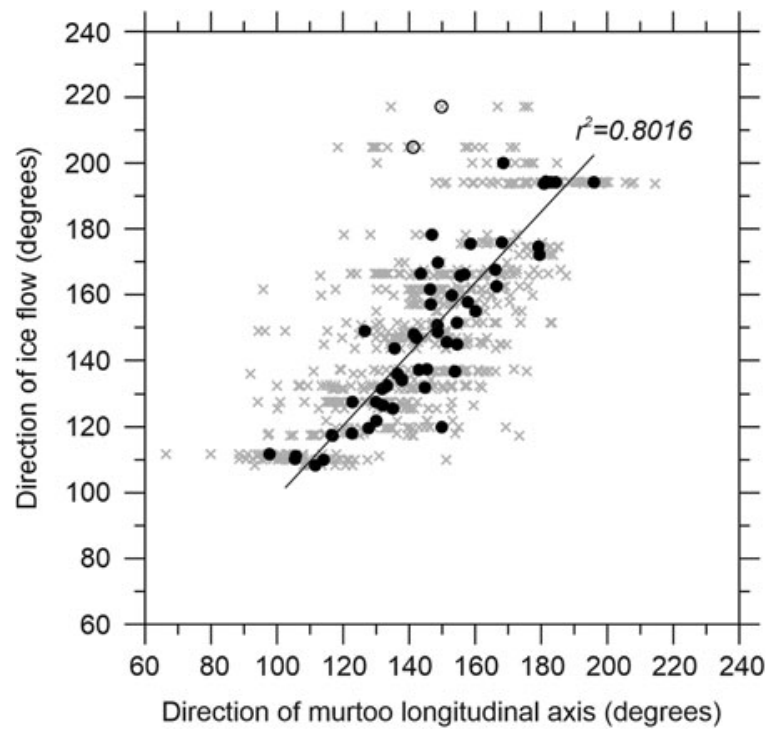

Fig. 7. Relationship between the murtoo orientation and the local ice-flow direction of the Late Weichselian. Gray crosses are directions of individual murtoos and black dots indicate the mean orientation of murtoos in each murtoo field. The solid line is a linear regression $\left(r^{2}=0.8016\right)$ between these two variables excluding two outliers marked with open circles. 

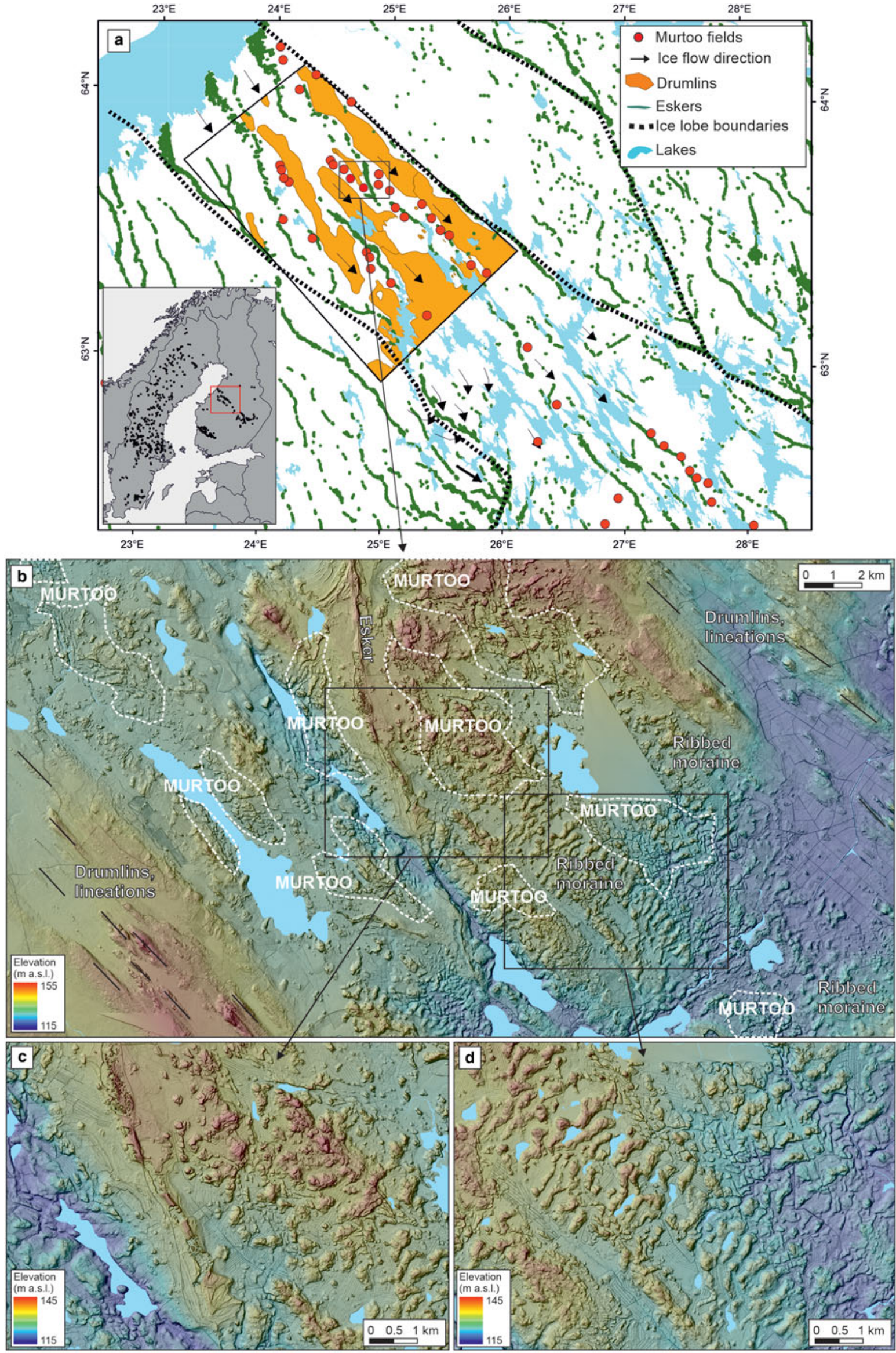

Fig. 8. Morphological map (a) and LiDAR DEM of murtoo field arrangement along the hummocky margins of the ice-flow corridors (drumlinized) within the rapidly deglaciated trunk of the Finnish Lake District Ice Lobe (b) (interpretations in (a) by Ahokangas and Mäkinen, 2014). Murtoos occur in corridors in close association with eskers (c) and cut ribbed moraines (d). 
Fig. 9. Morphological map covering parts of northern Sweden displaying murtoo fields and their spatial relation to Veiki moraine and ribbed moraine. Observe the absence of murtoo fields in the vicinity of Veiki moraine and the presence of murtoos fields in areas of ribbed moraine. Distribution of Veiki and ribbed moraines is simplified from Hättestrand (1998).

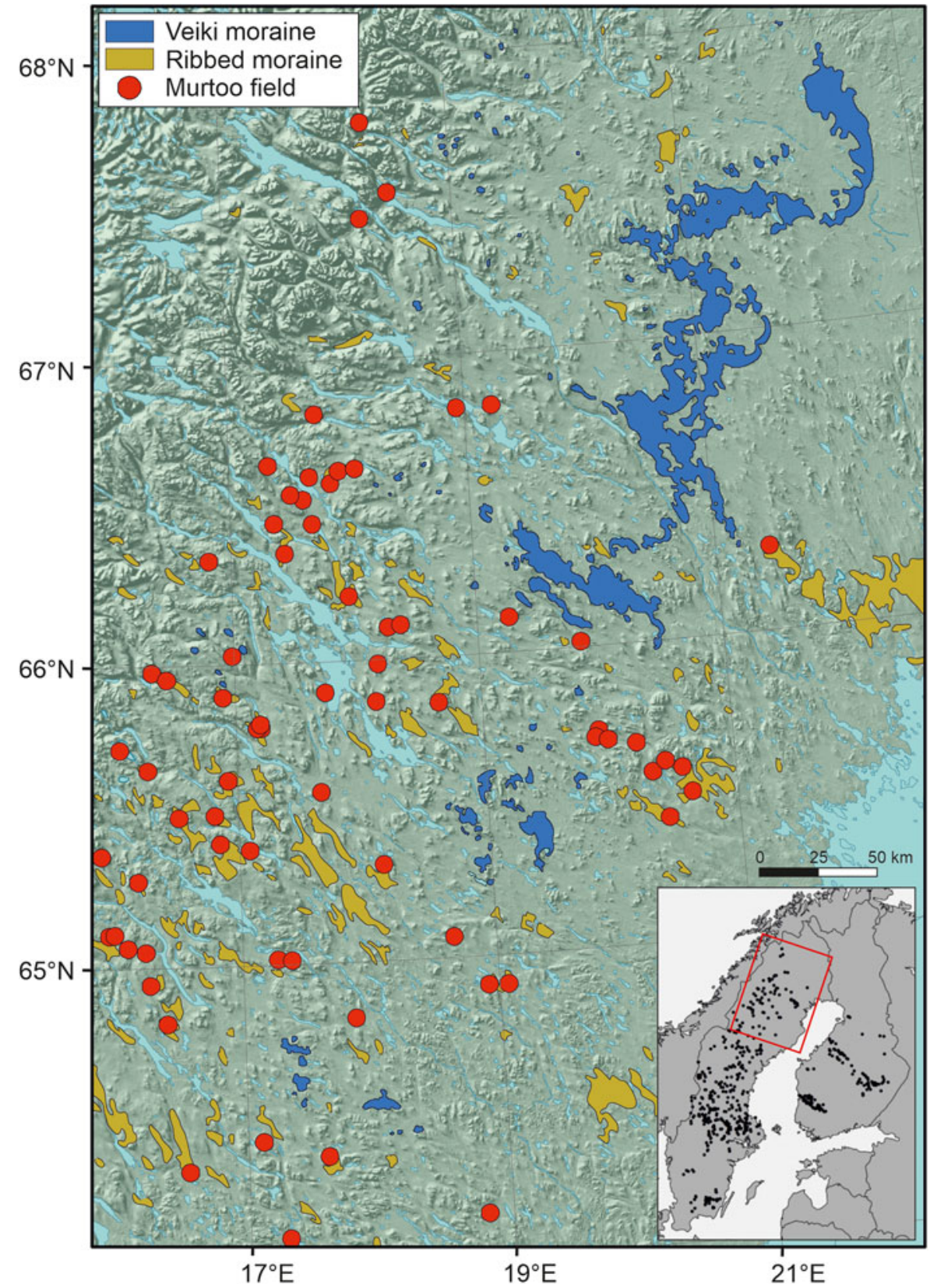

occurring up-flow from eskers (Fig. 8) (Mäkinen and others, 2017). Murtoo fields are related to ribbed moraines (Fig. 8). When found together, the murtoos truncate rib forms indicating that they were formed after ribbed moraines.

Figure 9 shows the relationship between the distribution of murtoo fields and Veiki moraine in northern Sweden. Individual Veiki moraines have been shown to be Early Weichselian ice-walled-lake plains that were preserved under cold-bed conditions during the Late Weichselian (Lagerbäck, 1988; Hättestrand, 1998). Veiki moraine is well preserved in the north of Sweden where murtoos are completely absent, but these moraines appear in patches among the northernmost murtoos.

Finally, in places, murtoos have flute-like lineations on their upper surfaces that are parallel to the most recent local ice flow indicating overriding ice (Johnson and others, 2018).

\section{Murtoo distribution}

Figure 10 shows the distribution of the murtoo fields of the present study. We chose that to qualify as a murtoo 'field' at least five distinct individual murtoos needed to be present. Altogether, we identified 564 murtoo fields in Finland and Sweden. We note, however, that we have observed locations with landforms somewhat similar to murtoos (sharp edges, shingled appearance, etc.), but have excluded them from the analysis because the forms did not exhibit the distinct triangular form or the triangular forms were too few. This suggests that the environment in which the murtoos were formed may have been more widespread than our mapped points indicate.

Distinct murtoos are predominantly found in areas that have relatively low relief, although in the central Sweden region murtoos also occur axially to valleys that radiate out from the Scandes Mountains. Preliminary landscape-classification analyses show that at least most (up to 75\%) of the murtoo fields are found in landscapes that slope down ice. Importantly, murtoos are found above and below the marine limit in both countries indicating that their formation is not fixed to a supra- or subaquatic environment.

The southernmost occurrences of murtoos within the studied area are in southern Sweden, where the ice margin retreated during 


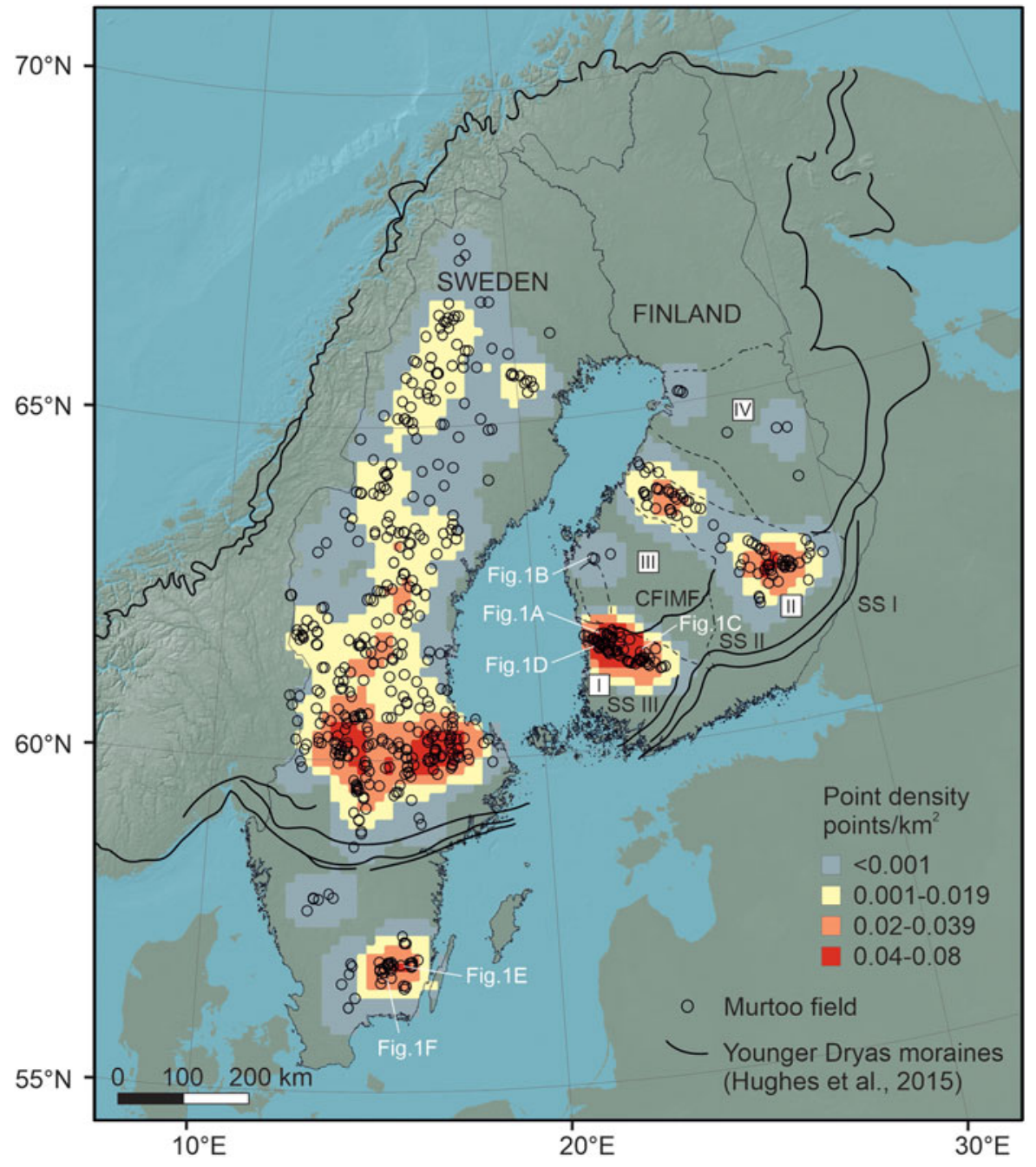

Fig. 10. Distribution of distinct murtoo fields in the Scandinavian Ice Sheet area in Finland and Sweden. Location of examples in Figure 1 is shown. Solid black lines indicate Younger Dryas end moraines (Hughes and others, 2015), including the Middle Swedish end moraine zone (MSEMZ) and Salpausselkäs (SS I, SS II, SS III) and Central Finland Ice Marginal Formation (CFIMF). Dashed lines indicate boundaries of the main Late Weichselian ice stream lobes in Finland (Putkinen and others, 2017). The Finnish ice lobes discussed in the paper are indicated with Roman numerals: (I) the Baltic Sea ice lobe, (II) the Finnish Lake District ice lobe, (III) the Näsijärvi-Jyväskylä ice lobe and (IV) the North Karelian ice lobe. the warm Bølling-Allerød interstadial. North of the southernmost occurrence of murtoos, these forms are generally absent until $\sim 40-50 \mathrm{~km}$ north of the prominent moraine systems that mark the Middle Swedish end-moraine zone and the Salpausselkä zone, which were formed during the Younger Dryas cold period (Hughes and others, 2015; Stroeven and others, 2016). The frequency of murtoos increases significantly $50-100 \mathrm{~km}$ north of the Younger Dryas end moraines (Fig. 10).

Significantly, murtoos appear to be completely absent from the northern Fennoscandian region, where it has been shown that the SIS was cold-based during much of the Weichselian (Lagerbäck and Robertson, 1998; Kleman and Hättestrand, 1999).

In general, murtoo fields mapped in southern and central Sweden show a dispersed character within the regions they occur, but in southern and central Finland, it is common for murtoo fields to occur in distinct corridors parallel to the regional ice flow and closely associated with eskers (Figs 8 and 10) (Mäkinen and others, 2017; Peterson and others, 2017).

In southern and central Finland, the majority of murtoos are associated with the Baltic Sea and Finnish Lake District ice lobes, although some scattered murtoos and murtoo fields are also found in the North Karelia ice lobe in central Finland and in the western sector of the Näsijärvi-Jyväskylä ice lobe (Fig. 10). The Finnish Lake District ice lobe has two murtoo areas clustered in the NW and SE parts. In the NW of this district, murtoos form corridors along the margins of drumlinized iceflow corridors partly associated with ribbed moraines (Figs 8 and 10) (cf. Ahokangas and Mäkinen, 2014).
The SE part of the Finnish Lake District ice lobe shows two clear corridors, tens of $\mathrm{km}$ long and mostly $2-4 \mathrm{~km}$ wide that are dotted by murtoo fields along the central axis of the ice lobe (the eastern corridor is well depicted in Fig. 10), splitting the lobe axially and separating drumlinized terrain into different flow sectors. The murtoo corridors here occur up-ice of prominent eskers that end at the Salpausselkäs. Additionally, the murtoos are commonly found on the lee of topographic highs or their margins. The third cluster of murtoos in Finland occurs along the northeastern margin of the Baltic Sea ice lobe (Loimaa sublobe) (Mäkinen, 2003; Mäkinen and others, 2017). Here, murtoos are found $\sim 50-150 \mathrm{~km}$ up-ice from the Salpausselkä III.

\section{Discussion}

\section{Murtoos are a distinct landform}

The geomorphologically distinct and unique appearance of murtoos suggested by Mäkinen and others (2017) and Peterson and others (2017) is supported here by morphometric analysis. Not only is the triangular form readily recognizable on the LiDAR data, but the distribution of the values for length, width, area, slope and tip angle reveal distinct populations with a normal to log-normal distribution. Furthermore, scatter plots comparing slope and height, width and length, and tip angle and height show either strong correlation or clear relationships, thus indicating a common $\mathrm{V}$-shaped appearance within the study area. These strong relationships are not unlike those reported for the 
morphometric length-width relationships in drumlins (e.g. Clark and others, 2009).

Compared with other glacial landforms, murtoos are most similar to glacial hummocks, which are commonly interpreted to be formed by stagnant ice. Indeed, murtoo fields that were identified in Sweden and Finland have, in some cases, earlier been mapped as 'hummocky moraines' or 'dead-ice moraines' (e.g. Virkkala, 1962; Perttunen and others, 1984; Malmberg Persson and Persson, 2011), which is not surprising because the distinctive morphological characteristics of murtoos in these heavily forested terrains is hard to discern without LiDAR. The relief, width and length of reported glacial hummocks are similar to the murtoos we describe here, although hummocks can be of much higher relief in some places (Johnson and Clayton, 2003; Utting and others, 2009). However, the shape of glacial hummocks is commonly reported as 'chaotic,' 'disorganized' or 'irregular' (e.g. Clayton and Moran, 1982; Paul, 1983; Johnson and Clayton, 2003; Peterson and others, 2017). The distinct V-shape of murtoos contrasts with this description, and Peterson and others (2017) were able to distinguish readily between their V-shaped hummocks and fields of 'disorganized and irregular' hummocks in southern Sweden. Some glacial hummocks have been reported to have a preferred orientation (Gravenor and Kupsch, 1959; Johnson and others, 1995; Munro and Shaw, 1997; Sjogren and others, 2002), but none shown in these studies bears the distinct triangular shape of murtoos. We therefore consider that murtoos described in the present study are distinct from the glacial hummocks reported in the literature.

Murtoos are also distinct from ribbed moraine, a landform with which they are commonly found (Fig. 8). The morphology of ribbed moraine can vary greatly. For example, Dunlop and Clark (2006) identified and named 16 forms of ribbed moraine. However, the morphology of murtoos is dissimilar to all 16 types. The shingled and V-shape characteristics of murtoos are distinctly different than the transverse ridges of ribbed moraine. Moreover, the cross-cutting nature of murtoos with ribbed moraine (Fig. 8) indicates that murtoos were formed by a different or modified process from that of ribbed moraines, and that the murtoos are younger. We therefore consider murtoos distinct from ribbed moraine.

\section{Distribution of murtoos}

The spatial distribution of murtoos is first and foremost related to periods of rapid ice retreat (Fig. 10). The timing of ice retreat over these areas coincides with the Bølling-Allerød interstadial (in Sweden) and the early Holocene warming during deglaciation following the Younger Dryas (in Sweden and Finland) (Deschamps and others, 2012; Rasmussen and others, 2014). In southern Sweden during the Bølling-Allerød, the ice sheet retreated over $100 \mathrm{~m}$ per year (Ringberg, 1979; Stroeven and others, 2016). During the early Holocene, retreat rates were $100-400 \mathrm{~m}$ per year in Sweden and Finland (Boulton and others, 2001; Stroeven and others, 2016), during which a significant fraction of the meltwater generated was delivered to the bed. The timing and amount of supra- and subglacial melting is an important driver of glacial dynamics, as recognized on contemporary ice sheets (Das and others, 2008; Meierbachtol and others, 2013; Andrews and others, 2014). We suggest that the concentrated delivery of meltwater created conditions suitable for murtoo formation as shown in Figures 8 and 10.

The area of overlap between Veiki moraines (Lagerbäck, 1988; Hättestrand, 1998) and murtoos in northern Sweden (Fig. 9) suggests that bed conditions had changed from frozen to thawed when murtoos were forming.

It is evident that the distribution of murtoos in the area covered by the SIS can also be partly explained by ice-sheet dynamics.
The SIS was split into distinct ice lobes in southern and central Finland, but not in southern and central Sweden, and the murtoo distribution in Finland is clearly related to the pattern of these lobes. These lobes have also been interpreted to have experienced surging or streaming behavior (Kleman and others, 1997; Stroeven and others, 2016), a behavior not recognized in the Swedish mainland. Clusters of murtoo fields within the Finnish Lake District ice lobe could reflect the reorganization of the ice flow during deglaciation. The NW cluster of murtoos is related to deglaciation along the trunk of the Finnish Lake District ice lobe with deepening proglacial water (Ahokangas and Mäkinen, 2014).

Lastly, we note that murtoos first appear $40-50 \mathrm{~km}$ north of the Younger Dryas moraines. The absence of murtoos around the Younger Dryas end-moraine zone suggests they were not formed during the cold event, and that conditions for their formation existed only after the Younger Dryas. If the formative conditions of murtoos began at the onset of Early Holocene warming when the ice margin was at the Younger Dryas end-moraine zone, this indicates that murtoos form $40-50 \mathrm{~km}$ from the margin. However, if the conditions developed later during ice-margin retreat, murtoos would be formed closer to the ice margin. This idea can be supported by noting that other warm-bed landforms, such as drumlins (e.g. Mooers, 1989) and eskers (Storrar and others, 2013) can form near the ice margin. In their model of the SIS dynamics, Kleman and others (2008) suggested that the active warm-bed part of the ice sheet, where we propose murtoos to form, only occurs close to the ice margin. The present and earlier observations (Mäkinen and others, 2017) indicate that murtoos often occur upstream of eskers further away from the ice margin, and thus in a zone of higher subglacial water pressure. Greenwood and others (2016) consider dendritic channelized topology to generally be limited to $50 \mathrm{~km}$ from the ice margin.

\section{Murtoo formation environment}

Based on their spatial distribution, murtoos are formed on a thawed bed during times of rapid ice-margin retreat when large quantities of supraglacial meltwater would be delivered to the bed. Thereby, murtoos could represent landforms that developed towards the ice-sheet interior to evacuate large discharges of subglacial water under high pressure prior to the development of flow in large meltwater tunnels or Röthlisberger channels. The appearance of murtoos in corridors, especially in areas of past ice streams in southern and central Finland, could thus partly explain changing subglacial hydrology and how eskers extend themselves headward during the deglaciation (Banerjee and McDonald, 1975).

Understanding of ice-sheet hydrology is essential because it affects mass balance through its impact on meltwater runoff processes and ice dynamics (Nienow and others, 2017). Formation of murtoos could be associated with rapid supraglacial lake drainages like those in Greenland today (Meierbachtol and others, 2013; Flowers, 2015), in which high discharges of meltwater are evacuated through transient and distributed subglacial hydrologic systems (Dow and others, 2015). If murtoos indeed indicate high subglacial discharges associated with rapidly melting ice sheets, they could contribute significantly to improving palaeoglaciological models.

\section{Conclusions}

- Murtoos are a morphologically distinct glacial landform.

- The ice-sheet scale distribution of murtoo fields can be explained by ice-retreat rate and glacial dynamics. They occur in places characterized by rapid ice retreat (deglaciation during 
Bölling-Alleröd and early Holocene). Additionally, in southern and central Finland, where the SIS was broken into dynamic ice lobes, murtoos occur in corridors along lobe axes and margins.

- The main constraints for the formation of murtoos are that they formed: (i) during rapid deglaciation in a warming climate, (ii) under warm-based ice, (iii) in association with significant subglacial meltwater flow and (iv) in non-channelized environment.

Acknowledgements. We wish to thank Izabella Remmert and Julia Kristiansson whose bachelor theses provided a testing ground for a number of our morphometric measurements. We are grateful to Jakob Heyman, Jan Lundqvist, Mats Olvmo, Niko Putkinen and Erik Sturkell for constructive comments and discussions. We also thank Timothy Fisher, Matthew Bennett and Neal Iverson for their valuable help, suggestions and criticism. This work was supported by the Academy of Finland (Antti E.K. Ojala: grant number 322252 and Joni Mäkinen: grant number 322243) and SGU (Mark Johnson: grant number 36-1772/2014).

\section{Author contributions}

Conceived and interpreted the 'murtoo' landform: J.M., M.J., J.-P.P., G.P., K.K., A.E.K.O., E.A. Performed LiDAR screening and 'murtoo' measurements and classification: A.E.K.O., G.P., K.K., C.Ö., J.-P.P., M.J., E.A. Analyzed the data: J.M., M.J., K.K., G.P., J.-P.P., A.E.K.O., C.Ö. Wrote the paper: A.E.K.O., M.J., J.M., K.K., G.P., E.A., J.-P.P. Critically revised, improved and approved the final manuscript: A.E.K.O., J.M., G.P., M.J., K.K., E.A., J.-P.P., C.Ö.

\section{Conflict of interest}

The authors declare that no competing interests exist.

\section{References}

Ahokangas E and Mäkinen J (2014) Sedimentology of an ice margin esker with implications for the deglacial dynamics of the Finnish Lake District lobe trunk. Boreas 43(1), 90-116. doi: 10.1111/bor.12023.

Andrews LC and 7 others (2014) Direct observations of evolving subglacial drainage beneath the Greenland Ice Sheet. Nature 514, 80-83. doi: 10.1038/nature13796.

Banerjee I and McDonald BC (1975) Nature of esker sedimentation. In Jopling AV and McDonald BC (eds), Glaciofluvial and Glaciolacustrine Sedimentation, vol. 23. Tulsa, Oklahoma: Society of Economic Paleontologists and Mineralogists, Special Publication, pp. 133-154.

Boulton GS, Dongelmans P, Punkari M and Broadgate M (2001) Palaeoglaciology of an ice sheet through a glacial cycle: the European ice sheet through the Weichselian. Quaternary Science Reviews 20(4), 591625. doi: 10.1016/S0277-3791(00)00160-8.

Clark CD, Hughes AL, Greenwood SL, Spagnolo M and Ng FS (2009) Size and shape characteristics of drumlins, derived from a large sample, and associated scaling laws. Quaternary Science Reviews 28(7-8), 677-692. doi: 10.1016/j.quascirev.2008.08.035.

Clayton L and Moran SR (1982) Chronology of Late Wisconsinan glaciations in middle North America. Quaternary Science Reviews 1, 55-82.

Das SB and 6 others (2008) Fracture propagation to the base of the Greenland ice sheet during supraglacial lake drainage. Science 320(5877), 778-781. doi: $10.1126 /$ science. 1153360 .

Deschamps P and 8 others (2012) Ice-sheet collapse and sea-level rise at the Bølling warming 14,600 years ago. Nature 483, 559-564. doi: 10.1038/ nature10902.

Dow CF and 10 others (2015) Modeling of subglacial hydrological development following rapid supraglacial lake drainage. Journal of Geophysical Research: Earth Surface 120(6), 1127-1147. doi: 10.1002/2014JF003333.

Dunlop P and Clark CD (2006) The morphological characteristics of ribbed moraine. Quaternary Science Reviews 25(13-14), 1668-1691. doi: 10.1016/j. quascirev.2006.01.002.

Flowers GE (2015) Modelling water flow under glaciers and ice sheets. Proceedings of the Royal Society of London. Series A 471(2176), 20140907. doi: 10.1098/rspa.2014.0907.
Frödin G (1954) De sista skedena av centraljämtlands glaciala historia. Geographica. 24, 1-251.

Gravenor CP and Kupsch WO (1959) Ice-disintegration features in western Canada. Journal of Geology 67(1), 48-64.

Greenwood SL, Clason CC, Helanow C and Margold M (2016) Theoretical, contemporary observational and palaeo-perspectives on ice sheet hydrology: processes and products. Earth-Science Reviews 155, 1-27. doi: 10.1016/j.earscirev.2016.01.010

Hättestrand C (1998) The glacial geomorphology of central and northern Sweden. Sveriges Geologiska Undersökning 85, 1-47.

Hughes ALC, Gyllencreutz R, Lohne ØS, Mangerud J and Svendsen JI (2015) The last Eurasian ice sheets - a chronological database and time-slice reconstruction, DATED-1. Boreas 45(1), 1-45. doi: 10.1111/bor.12142.

Jasiewicz J and Stepinski TF (2013) Geomorphons - a pattern recognition approach to classification and mapping of landforms. Geomorphology 182, 147-156. doi: 10.1016/j.geomorph.2012.11.005.

Jenness J (2013) DEM surface tools. Jenness enterprises. Available at http:// www.jennessent.com/arcgis/surface_area.htm.

Johansson P, Lunkka JP and Sarala P (2011) The glaciation of Finland. Developments in Quaternary Sciences 15, 105-116. doi: 10.1016/ B978-0-444-53447-7.00009-X.

Johnson MD and Clayton L (2003) Supraglacial landsystems in lowland terrain. In Evans D (ed.), Glacial Landsystems. London: Arnold, pp. 228258. doi: 10.4324/9780203784976.

Johnson MD, Mickelson DM, Clayton L and Attig JW (1995) Composition and genesis of glacial hummocks, western Wisconsin, USA. Boreas 24(2), 97-116. doi: 10.1111/j.1502-3885.1995.tb00630.x.

Johnson M and 7 others (2018) Geomorphology and distribution of subglacial triangular hummocs (murtoos) in Sweden and Finland. In Belmonte L and 16 others (eds), Abstracts of the Nordic Geological Winter Meeting 2018, 10-12.1.2018, Copenhagen, Denmark: Geological Society of Denmark, p. 172.

Kajuutti K, Mäkinen J, Ahokangas E, Ojala A and Palmu J-P (2018) New subglacial landforms detected from LiDAR data. In Belmonte L and 16 others (eds), Abstracts of the Nordic Geological Winter Meeting 2018, 10-12.1.2018, Copenhagen, Copenhagen: Geological Society of Denmark, p. 175.

Kleman J and Hättestrand C (1999) Frozen-bed Fennoscandian and Laurentide ice sheets during the Last Glacial Maximum. Nature 402, 63-66.

Kleman J, Hättestrand C, Borgström I and Stroeven A (1997) Fennoscandian palaeoglaciology reconstructed using a glacial geological inversion model. Journal of Glaciology 43, 283-299.

Kleman J, Stroeven AP and Lundqvist J (2008) Patterns of Quaternary ice sheet erosion and deposition in Fennoscandia and a theoretical framework for explanation. Geomorphology 97, 73-90.

Koistinen T and 5 others (2001) Geological Map of the Fennoscandian Shield, Scale 1:2 000 000. Trondheim: Geological Survey of Norway, Uppsala: Geological Survey of Sweden, Moscow: Ministry of Natural Resources of Russia, Espoo: Geological Survey of Finland.

Lagerbäck R (1988) The Veiki moraines in northern Sweden-widespread evidence of an Early Weichselian deglaciation. Boreas 17, 469-486. doi: 10.1111/j.1502-3885.1988.tb00562.x.

Lagerbäck R and Robertsson A (1998) Kettle holes-stratigraphical archives for Weichselian geology and palaeoenvironment in northernmost Sweden. Boreas 17(4), 439-468. doi: 10.1111/j.1502-3885.1988.tb00561.x.

Lundqvist J and Saarnisto M (1995) Summary of project IGCP-253. Quaternary International 28, 9-18. doi: 10.1016/1040-6182(95)00046-L.

Lundqvist J and Wohlfarth B (2001) Timing and east-west correlation of south Swedish ice marginal lines during the Late Weichselian. Quaternary Science Reviews 20, 1127-1148. doi: 10.1016/S0277-3791(00)00142-6.

Mäkinen J (2003) Development of depositional environments within the interlobate Säkylänharju-Virttaankangas glaciofluvial complex in SW Finland. Annales Academiae Scientiarum Fennicae. Series A3: Geologica Geographica 165, 1-165.

Mäkinen J, Kajuutti K, Palmu J-P, Ojala A and Ahokangas E (2017) Triangular-shaped landforms reveal subglacial drainage routes in SW Finland. Quaternary Science Reviews 164, 37-53. doi: 10.1016/j.quascirev. 2017.03.024.

Mäkinen J, Kajuutti K, Ahokangas E, Ojala AEK and Palmu J-P (2018) Sedimentology of murtoos - new subglacial landforms detected from LiDAR data in SW Finland. In Belmonte L and 16 others (eds), Abstracts of the Nordic Geological Winter Meeting 2018, 10-12.1.2018, Copenhagen, Denmark: Geological Society of Denmark, pp. 176-177. 
Malmberg Persson K and Persson M (2011) Jordartskartan 4F Lessebo NV, Geological Survey of Sweden map, K 359, scale 1:100 000.

Meierbachtol T, Harper J and Humphrey N (2013) Basal drainage system response to increasing surface melt on the Greenland ice sheet. Science 341(6147), 777-779. doi: 10.1126/science.1235905.

Mooers HD (1989). Drumlin formation: a time transgressive model. Boreas 18(2), 99-107. doi: 10.1111/j.1502-3885.1989.tb00379.x.

Munro M and Shaw J (1997) Erosional origin of hummocky terrain in southcentral Alberta, Canada. Geology 25(11), 1027-1030. doi: 10.1130/ 0091-7613(1997)025<1027:EOOHTI>2.3.CO;2.

Nienow PW, Sole AJ, Slater DA and Cowton TR (2017) Recent advances in our understanding of the role of meltwater in the Greenland Ice Sheet System. Current Climate Change Reports 3(4), 330-344. doi: 10.1007/s40641-017-0083-9.

Paul MA (1983) The supraglacial landsystem. In Eyles N (ed.), Glacial Geology. Oxford: Pergamon, pp. 71-90.

Perttunen M, Stén C-G, Hyyppä J and Grönlund T (1984) Explanation to the map of superficial deposits, Sheet 2114 Toijala. Geological Survey of Finland, Espoo. p. 63.

Peterson G, Johnson M and Smith C (2017) Glacial geomorphology of the south Swedish uplands - focus on the spatial distribution of hummock tracts. Journal of Maps 13(2), 534-544. doi: 10.1080/17445647.2017.1336121.

Peterson G, Johnson M and Öhrling C (2018). Sedimentological and morphological implications for the understanding of murtoo formation in Sweden. In Belmonte L and 16 others (eds), Abstracts of the Nordic Geological Winter Meeting 2018, 10-12.1.2018, Copenhagen, Denmark, p. 177.

Putkinen N and 13 others (2017) High-resolution LiDAR mapping of ice stream lobes in Finland. Bulletin of the Geological Society of Finland 89 (2), 64-81. doi: 10.17741/bgsf/89.2.001.
Rasmussen SO and 23 others (2014) A stratigraphic framework for abrupt climatic changes during the Last Glacial period based on three synchronized Greenland ice-core records: refining and extending the INTIMATE event stratigraphy. Quaternary Science Reviews 106, 14-28. doi: 10.1016/j.quascirev. 2014.09.007.

Regnéll C, Mangerud J and Svendsen JI (2019) Tracing the last remnants of the Scandinavian Ice Sheet: ice-dammed lakes and a catastrophic outburst flood in northern Sweden. Quaternary Science Reviews 221, 105862. doi: 10.1016/j.quascirev.2019.105862.

Ringberg B (1979) Varve chronology of the glacial sediments in Blekinge and northeastern Skåne, southeastern Sweden. Boreas 8(2), 209-215. doi: 10.1111/j.1502-3885.1979.tb00802.x.

Seppälä MVJ (2016) Lidar-based detection and interpretation of glaciotectonic features of the morainic topography of Finland. Journal of Geological Research 2016, 4292806. doi: 10.1155/2016/4292806.

Sjogren DB, Fisher TG, Taylor LD, Jol HM and Munro-Stasiuk MJ (2002) Incipient tunnel channels. Quaternary International 90(1), 41-56. doi: 10.1016/S1040-6182(01)00091-X.

Storrar RD, Stokes CR and Evans DJ (2013) A map of large Canadian eskers from Landsat satellite imagery. Journal of Maps 9(3), 456-473. doi: 10.1080/ 17445647.2013.815591.

Stroeven AP and 15 others (2016) Deglaciation of Fennoscandia. Quaternary Science Reviews 147, 91-121. doi: 10.1016/j.quascirev.2015.09.016.

Utting DJ, Ward BC and Little EC (2009) Genesis of hummocks in glaciofluvial corridors near the Keewatin Ice Divide, Canada. Boreas 38(3), 471-481. doi: 10.1111/j.1502-3885.2008.00074.x.

Virkkala K (1962) Explanation to the map of superficial deposits, Sheet 2123, Tampere. Geological Survey of Finland, Espoo. p. 70. 